\title{
Complement, leukocytes, and leukocyte elastase in full-term neonates undergoing cardiac operation
}

In 13 neonates undergoing cardiac operations for congenital cardiac defects, complement, leukocytes, and leukocyte elastase were studied during and after cardiopulmonary bypass. All but two neonates received prostaglandin $E_{1}$ before the operation. The $C 3 d / C 3$ ratio rose significantly during cardiopulmonary bypass from $0.86 \pm 0.55$ to $1.40 \pm 0.56$ (mean \pm standard deviation; $p<0.0001$ ). Abnormally elevated C5a levels $(18.6 \pm 7.3 \mu \mathrm{g} / \mathrm{L})$ were measured at the end of cardiopulmonary bypass. $\mathrm{C} 4$ was not overtly consumed during the procedure. Leukocytes fell from a preoperative value of $10.06 \pm 3.15 \times 10^{9} / \mathrm{L}$ to $3.21 \pm 0.64 \times 10^{9} / \mathrm{L}$ after beginning of cardiopulmonary bypass $(p<0.0001)$ and rose at the end of the procedure from $2.33 \pm 0.67 \times 10^{9} / \mathrm{L}$ to $7.19 \pm 1.84 \times 10^{9} / \mathrm{L}$, after protamine administration $(\mathbf{p}<0.0001)$. Neutrophils fell from a preoperative value of $5.14 \pm 1.18 \times 10^{9} / \mathrm{L}$ to $1.46 \pm 0.35 \times 10^{9} / \mathrm{L}$ after beginning of cardiopulmonary bypass and rose at the end of extracorporeal circulation from $1.00 \pm 0.31 \times 10^{9} / \mathrm{L}$ to $4.10 \pm 1.18 \times 10^{9} / \mathrm{L}$, after protamine administration $(p<0.005)$. Elastase release occurred in all neonates during cardiopulmonary bypass and averaged $331.5 \pm 175.7 \mu \mathrm{g} / \mathrm{L}$. Complement activation and leukocyte stimulation did not correlate with postoperative complications or outcome. This study demonstrates complement activation and leukocyte stimulation in neonates undergoing cardiac operation. (J THORAC CardiovasC SuRG 1994;108:29-36)

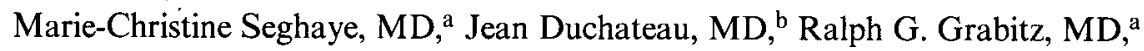

Gloria Nitsch, MD, ${ }^{\text {a }}$ Christiane Marcus, MD, ${ }^{\mathrm{c}}$ Bruno J. Messmer, MD, ${ }^{\mathrm{d}}$

and Götz von Bernuth, MD, ${ }^{a}$ Aachen, Germany, and Brussels, Belgium

$\mathrm{C}$ ardiopulmonary bypass $(\mathrm{CPB})$ in adults and children may be responsible for several postoperative complications that are basically due to activated complement resulting in anaphylatoxin liberation and leukocyte stimulation. ${ }^{1,2}$ Because full-term neonates are reported to have subnormal activity of the alternative pathway of the complement system compared with that of adults ${ }^{3,4}$ and immaturity of complement receptors on neutrophils, ${ }^{5}$ we investigated their response to $\mathrm{CPB}$ with regard to com-

From the Department of Pediatric Cardiology, RWTH Aachen, Germany ${ }^{\mathrm{a}}$; the Department of Immunology, St. Pierre Hospital, Brussels, Belgium ${ }^{\mathrm{b}}$; and the Departments of Anesthesiologyc and Cardiothoracic Surgery, ${ }^{\text {d }}$ RWTH Aachen, Germany.

Supported, in part, by the grant "Fondation Léon Frédéricq," Liège, Belgium (M.-C. S.)

Address for reprints. M.-C. Seghaye, MD, Department of Pediatric Cardiology, RWTH Aachen, 52057 Aachen, Germany.

Received for publication June 21, 1993.

Accepted for publication Dec. 14, 1993.

Copyright $(1994$ by Mosby-Year Book, Inc.

$0022-5223 / 94 \$ 3.00+0 \quad \mathbf{1 2 / 1 / 5 3 6 9 0}$ plement activation and leukocyte stimulation and considered a possible correlation between inflammatory response and postoperative outcome.

\section{Patients and methods}

The study included 13 full-term consecutive neonates ( 10 boys, 3 girls) aged 4 to 8 days (median 6 days) undergoing cardiac operations for congenital heart disease in our institution. Diagnosis, age, and weight at time of operation are shown in Table I. All but two neonates were treated with prostaglandin $\mathrm{E}_{1}\left(\mathrm{PGE}_{1}\right)$ before operation. Cardiac catheterization with angiocardiography was performed in all patients 1 to 7 days (median 3 days) before the operation. The lungs of eight neonates were mechanically ventilated before the operation. Routine laboratory investigations were in normal range before the operation in all patients. Materno-fetal infection was excluded in all cases.

Anesthesia and antibiotic regimen. General anesthesia and myoplegia were performed with diazepam, fentanyl, and pancuronium. As we do for infants and children, we administered dexamethasone to all neonates on the first postoperative day $(10$ $\mathrm{mg} / \mathrm{m}^{2}$ per day, administration was begun before sternotomy) and cefotiam hydrochloride $\left(75 \mathrm{mg} / \mathrm{kg}\right.$ per day). $\mathrm{PGE}_{1}$ administration was continued until CPB was begun.

CPB. The extracorporeal circuit was identical for the 13 
Table I. Clinical and perioperative data

\begin{tabular}{|c|c|c|c|c|c|c|c|c|c|}
\hline Patient No. & $\begin{array}{c}\text { Age } \\
\text { (days) }\end{array}$ & $\begin{array}{c}\text { Weight } \\
(\mathrm{gm})\end{array}$ & Diagnosis & Operative procedure & $\begin{array}{l}C P B \\
\text { (min) }\end{array}$ & $\begin{array}{l}C C A \\
(m i n)\end{array}$ & $\begin{array}{l}A X T \\
(\min )\end{array}$ & Complications & Outcome \\
\hline 1 & 6 & 3895 & $\begin{array}{l}\text { HypoRV, critical } \\
\text { PS }\end{array}$ & CoPV + RVOT enlargement & 49 & 40 & 45 & Hypoxia & Died \\
\hline 2 & 4 & 3200 & TAPVR(IC) & Correction & 35 & 26 & 29 & None & Well \\
\hline 3 & 8 & 2800 & TAPVR(C) & Correction & 47 & 27 & 29 & None & Well \\
\hline 4 & 7 & 3930 & D-TGA & ASO & 90 & 59 & 63 & $\begin{array}{l}\text { Digoxin } \\
\quad \text { overdose }\end{array}$ & Died \\
\hline 5 & 5 & 3450 & D-TGA & ASO & 84 & 60 & 62 & Anasarca & Well \\
\hline 6 & 4 & 3000 & D-TGA & ASO & 67 & 68 & 65 & None & Well \\
\hline 7 & 8 & 3250 & D-TGA & ASO & 73 & 63 & 88 & None & Well \\
\hline 8 & 5 & 3450 & D-TGA + SCO & Senning & 35 & 59 & 61 & $\mathrm{AF}$ & Well \\
\hline 9 & 4 & 3050 & D-TGA VSD & ASO & 98 & 68 & 67 & Anasarca & Well \\
\hline 10 & 5 & 3485 & D-TGA & ASO & 81 & 66 & 81 & None & Well \\
\hline 11 & 5 & 3700 & D-TGA & ASO & 63 & 51 & 53 & None & Well \\
\hline 12 & 6 & 3100 & D-TGA & ASO & 58 & 55 & 56 & Anasarca & Well \\
\hline 13 & 6 & 2885 & D-TGA & $\begin{array}{l}\text { ASO + AMI to RCA } \\
\text { bypass }\end{array}$ & 116 & 88 & 87 & $\begin{array}{l}\text { MI, shock, } \\
\text { chylothorax, } \\
\text { anasarca }\end{array}$ & Well \\
\hline
\end{tabular}

$C C A$, Cardiocirculatory arrest; $A X T$, aortic crossclamping time; $H y p o R V$, hypoplastic right ventricle; $P S$, pulmonary stenosis; $C o P V$, commisurotomy pulmonary valve; $R V O T$, right ventricular outflow tract; $T A P V R$, Total anomalous pulmonary venous return; $I C$, infracardial; $C$, cardial; $D$ - $T G A$, D-transposition of the great arteries; $A S O$, arterial switch operation; $S C O$, single coronary ostium; $A F$, atrial flutter; $V S D$, ventricular septal defect; $A M I$, arteria mammaria interna; $R C A$, right coronary artery; $M I$, myocardial infarction.

operations and consisted of a roller pump inducing a nonpulsatile flow (Stöckert Instrumente GmbH, Munich, Germany) and a disposable membrane oxygenator (VPCML; Cobe Laboratories, Inc., Lakewood, Colo.) with a heat exchanger and an arterial filter (Pall Corp., Glen Cove, N.Y.). The priming solution consisted of a crystalloid solution (Tutofusin Päd, Kabi Pharmacia, Erlangen, Germany), mannitol ( $3 \mathrm{ml} / \mathrm{kg}$ ), and compatible fresh whole blood. The hematocrit value of the circulating blood averaged $25 \%$. After median sternotomy and thymectomy, heparin sulfate was administered $(3 \mathrm{mg} / \mathrm{kg})$ and CPB was instituted with a perfusion index of $2.7 \mathrm{~L} / \mathrm{m}^{2}$ per minute. Deep hypothermia (nasopharyngeal temperature averaging $15^{\circ} \mathrm{C}$ ) was induced by cooling the priming solution in the extracorporeal circuit and the circulating blood with the heat exchanger. For vasodilatation during the cooling period, seven patients received phentolamine $(0.3$ to $0.5 \mathrm{mg} / \mathrm{kg})$, and six received sodium nitroprussid $(0.5$ to $1 \mu \mathrm{g} / \mathrm{kg}$ per minute). After deep hypothermia was reached, cardiocirculatory arrest was established after aortic crossclamping, and cardioplegia was induced by a single intraaortal injection of a $4^{\circ} \mathrm{C}$ cold Bretschneider solution $(30 \mathrm{ml} / \mathrm{kg})$. Circulatory arrest was maintained up to a maximum of 60 minutes. If necessary, the surgical procedure was continued under low-flow perfusion (about $25 \%$ of the initial flow rate). At the end of the procedure, normal flow was reestablished and the patient was rewarmed. One patient received phentolamine and four received sodium nitroprusside for vasodilatation in the rewarming period. Lungs were reventilated when core temperature reached $30^{\circ} \mathrm{C}$ and neutralization of heparin was achieved by protamine sulfate $(6 \mathrm{mg} / \mathrm{kg})$. If necessary, dopamine or epinephrine was infused before the patient was weaned off bypass.

Postoperative care. The lungs of all neonates were mechanically ventilated after the operation. Cardiac output was estimated clinically. Catecholamines (dopamine, epinephrine) and diuretics (furosemid) were infused to optimize blood pressure and diuresis. Laboratory studies including blood status, blood gases, electrolytes, renal and liver function tests, coagulation tests, and creatin phosphokinase were performed immediately after the operation and at least at 4 and 16 hours after the operation, as well as daily for the first postoperative week. Electrocardiography, echocardiography, chest roentgenography, and sonography of the pleural space, abdomen, and cerebrum were performed as often as necessary.

Collection of samples. Samples of venous blood were collected in the preoperative period from a peripheral vein, in the intraoperative and postoperative periods from a central venous catheter, and during CPB from the arterial line of the oxygenator. Sample collecting times are listed in Table II. For each sample $1.5 \mathrm{ml}$ of blood taken in tubes containing ethylendiaminetetraacetic acid were necessary for study of complement factors and leukocyte elastase, and, during CPB, a supplement of $0.3 \mathrm{ml}$ was required for leukocyte count and differentiation.

Determination of complement factors. Blood samples were immediately centrifuged for 3 minutes at $3000 \mathrm{rpm}$, and plasma was stored at $70^{\circ} \mathrm{C} . \mathrm{C} 3$ and $\mathrm{C} 4$ were determined by standard turbidimetry with the use of the immunoglobulin $G$ fraction of a rabbit anti-human $\mathrm{C} 3$ or $\mathrm{C} 4$ antiserum with an automated procedure on an RA 1000 turbidimeter (Technicon, Brussels, Belgium). Normal values for neonates were considered to range between $80 \%$ and $100 \%$ of normal values of healthy adults. ${ }^{6}$ For $\mathrm{C} 3 \mathrm{~d}$ determination, the sample was first incubated (vol/vol) with borate buffer containing $22 \%$ polyethylene glycol (molecular weight 6000 ) for 1 night at $4^{\circ} \mathrm{C}$. After centrifugation to discard the native $\mathrm{C} 3$ molecules, the supernatant containing the $\mathrm{C} 3 \mathrm{~d}$ was measured by turbidimetry (as was done for $\mathrm{C} 3$ and $\mathrm{C} 4$ ) with the following modifications: the sample diluant was supplemented with $20 \%$ distilled water to allow the reduction of polyethylene glycol to a maximum of $3.5 \%$ in the reaction mixture during immunoprecipitation.

C5a was determined by enzyme immunoassay (Enzygnost 
C5a, Behring; Hoechst, Brussels, Belgium). Normal values for healthy adults range between 0.15 and $0.45 \mu \mathrm{g} / \mathrm{L}$. Elastase was measured with immunoactivation enzyme immunoassay (Merck, Darmstadt, Germany). The normal range for healthy adults is $22 \pm 10 \mu \mathrm{g} / \mathrm{L}$.

Leukocyte count and differentiation was performed with a Coulter counter (Coulter Electronics, Inc. Hialea, Fla.). Leukocyte and neutrophil counts during CPB were corrected for hemodilution: determined values were multiplied by the ratio of preoperative hematocrit value (sample time 1) to hematocrit value at sampling. Complement fractions and elastase measured during $\mathrm{CPB}$ were not corrected for hemodilution. $\mathrm{C} 3 \mathrm{~d} / \mathrm{C} 3$ was used as index of $\mathrm{C} 3$ conversion independent of $\mathrm{C} 3$ concentration. The other values were analyzed under equal conditions of hemodilution, namely between the beginning (sample time 3) and the end of CPB (sample time 8) and between the first (sample time 9) and the seventh (sample time 13) postoperative days.

Statistical analysis. Results are expressed as the mean value \pm standard deviation (SD) or as the mean value \pm standard error of the mean (SEM). For statistical analysis parametric $t$ tests (paired and not paired) and nonparametric tests (Kruskal-Wallis test, Wilcoxon test) were used. For analysis of $\chi^{2}$, the Yates correction was always used. The data were computerized and analyzed with SPSS (SPSS Inc., Chicago, Ill.) and SAS (SAS Institute, Inc., Cary, N.C.) software, and $p$ values less than 0.05 were considered significant.

\section{Results}

Clinical results. Type of surgical correction and duration of CPB, cardiocirculatory arrest, and aortic crossclamping are listed in Table I. All neonates received catecholamines for coming off bypass (epinephrine 0.14 to $1.2 \mu \mathrm{g} / \mathrm{kg}$ per minute, median $0.4, n=12$; dopamine 2.9 to $8 \mu \mathrm{g} / \mathrm{kg}$ per minute, median $5.4, n=13$ ). Two patients (Nos. 1 and 4) died 48 and 24 hours after the operation from residual intracardiac shunt and digoxine overdose, respectively. One patient (No. 13) had myocardial infarction after arterial switch operation with consecutive low cardiac output and significant capillary leak syndrome. Three other neonates (Nos. 5, 9, and 12) had significant capillary leak syndrome with anasarca but without renal failure after arterial switch operation. Duration of mechanical ventilation in the survivors ranged between 3 and 21 days (median 7 days). Postoperative complications and outcome are summarized in Table I.

Hematocrit value. In the 13 patients, the hematocrit level fell from a preoperative value of $36.3 \% \pm 3.4 \%$ (mean \pm SD) to $27.5 \% \pm 2.2 \% 10$ minutes after beginning of CPB (sample time 3), due to hemodilution. The hematocrit level remained stable during $\mathrm{CPB}$ and increased slightly at sample time $8(32.6 \% \pm 4.5 \%)$. From the first postoperative day on, the hematocrit level was normal for age and remained stable until the end of the first postoperative week.
Table II. Sample time schedule

\begin{tabular}{cl} 
Sample time & Preoperative \\
\hline 1 & After heparin administration \\
3 & 10 minutes after onset of CPB \\
4 & After CCA \\
5 & 10 minutes after recirculation \\
6 & Lungs reventilated \\
7 & Core temperature $>30^{\circ} \mathrm{C}$ \\
8 & After protamine administration \\
9 & First postoperative day \\
10 & Second postoperative day \\
11 & Third postoperative day \\
12 & Fifth postoperative day \\
13 & Seventh postoperative day \\
\hline
\end{tabular}

$C C A$, Cardiopulmonary arrest.

\section{Complement factors}

C3. After institution of CPB (sample time 3), C3 levels fell in all neonates from a preoperative value of $85.9 \pm 27.4 \mathrm{mg} / \mathrm{dl}$ (mean $\pm \mathrm{SD}$ ) to $44.9 \pm 14.3 \mathrm{mg} / \mathrm{dl}$. $\mathrm{C} 3$ levels remained stable during $\mathrm{CPB}$ and after cardiocirculatory arrest, rising significantly between the end of the rewarming period (sample time 7) and protamine administration (sample time 8$)(p<0.05)$. From the third postoperative day on, $\mathrm{C} 3$ levels reached normal preoperative values (Fig. 1).

$C 3 d / C 3$. Nine neonates showed normal preoperative values of $\mathrm{C} 3 \mathrm{~d} / \mathrm{C} 3(\mathrm{C} 3 \mathrm{~d} / \mathrm{C} 3=0.50 \pm 0.13)$ (mean \pm $\mathrm{SD})$. In contrast, four other neonates had abnormally elevated $\mathrm{C} 3 \mathrm{~d} / \mathrm{C} 3$ ratio before the operation $(\mathrm{C} 3 \mathrm{~d} /$ $\mathrm{C} 3=1.59 \pm 0.11)$. Age at operation and at catheterization or delay between catheterization and operation, $\mathrm{PGE}_{1}$ dosage, preoperative leukocyte count, and CRP were identical in patients with normal and abnormally elevated preoperative values of $\mathrm{C} 3 \mathrm{~d} / \mathrm{C} 3$ (data not shown).

In these 13 neonates, $\mathrm{C} 3 \mathrm{~d} / \mathrm{C} 3$ levels increased significantly between the beginning of CPB (sample time 3 ) $(\mathrm{C} 3 \mathrm{~d} / \mathrm{C} 3=0.86 \pm 0.55)$ and the end of $\mathrm{CPB}$, after protamine administration (sample time 8$)(\mathrm{C} 3 \mathrm{~d} / \mathrm{C} 3=$ $1.40 \pm 0.56)(p<0.0001)$. C3 conversion was already significant from the beginning of the rewarming period on (sample time 6), compared with the beginning of CPB (sample time 3) $(p<0.05)$. In all neonates, C3d/C3 measured at sample time 8 correlated positively with the value measured at sample time $3(p<0.0005)$, as well as with the preoperative value $(p<0.05)$. Fig. 2 shows the course of $\mathrm{C} 3 \mathrm{~d} / \mathrm{C} 3$ in the 13 neonates, and Fig. 3 shows the course of $\mathrm{C} 3 \mathrm{~d} / \mathrm{C} 3$ in neonates with normal and with abnormally elevated preoperative $\mathrm{C} 3 \mathrm{~d} / \mathrm{C} 3$ values. In all patients, no correlation between duration of CPB and 


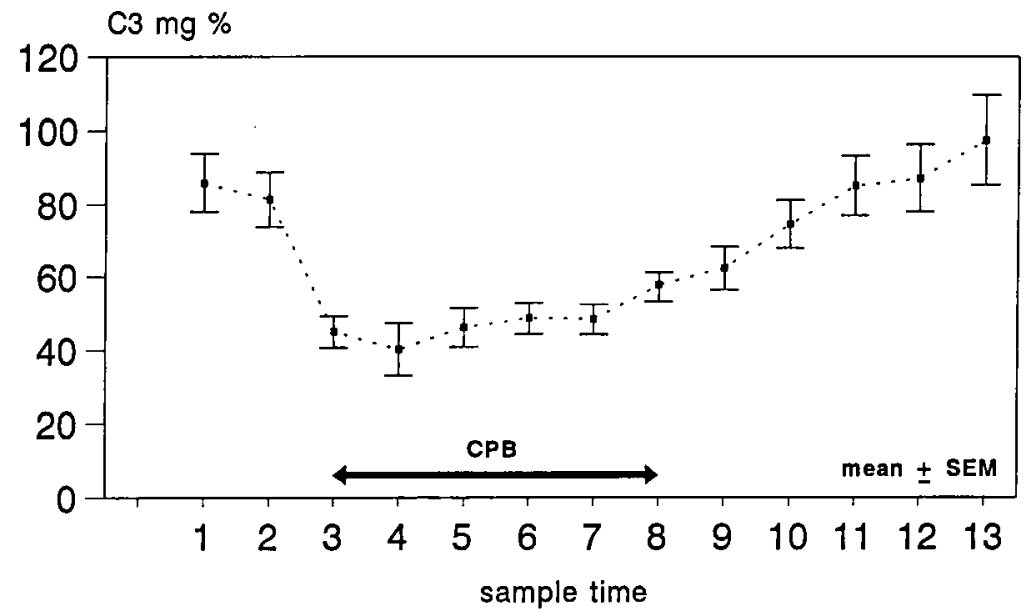

Fig. 1. Course of $\mathrm{C} 3$ before, during, and after CPB in 13 neonates (up to sample time $9, n=13$, and for sample times 10 to $13, n=11$ ). $m g \%$, Milligrams per deciliter.

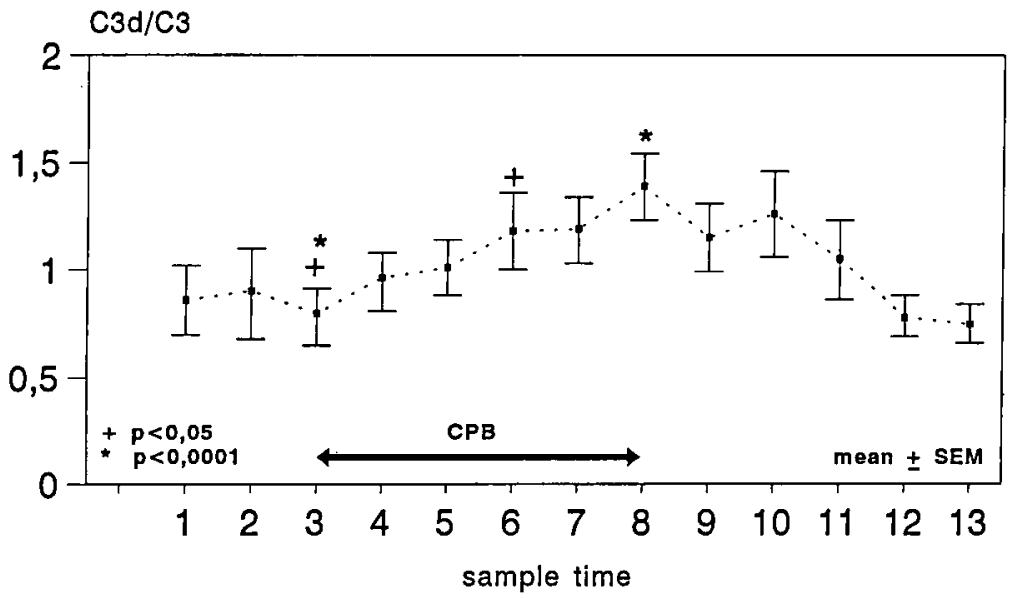

Fig. 2. Course of $\mathrm{C} 3 \mathrm{~d} / \mathrm{C} 3$ before, during, and after $\mathrm{CPB}$ (up to sample time $9, n=13$, and for sample times 10 to $13, n=11$ ).

$\mathrm{C} 3 \mathrm{~d} / \mathrm{C} 3$ value at sample time 8 or increase in $\mathrm{C} 3 \mathrm{~d} / \mathrm{C} 3$ levels during $\mathrm{CPB}(\mathrm{C} 3 \mathrm{~d} / \mathrm{C} 3$ at sample time $8-\mathrm{C} 3 \mathrm{~d} / \mathrm{C} 3$ at sample time 3) was found. $\mathrm{C} 3 \mathrm{~d} / \mathrm{C} 3$ ratios at the end of $\mathrm{CPB}$ and within the 3 first postoperative days did not correlate with catecholamine requirement at the end of operation or with outcome.

$C 4$. In the 13 neonates, $\mathrm{C} 4$ levels fell from a preoperative value of $14.6 \pm 4.7 \mathrm{mg} / \mathrm{dl}$ (mean $\pm \mathrm{SD}$ ) to a value of $8.5 \pm 4.0 \mathrm{mg} / \mathrm{dl} 10$ minutes after institution of $\mathrm{CPB}$ (sample time 3). C4 levels remained stable during CPB and increased slowly from the end of CPB on (sample time 8) within the 5 first postoperative days, reaching preoperative values (sample time 12). C4 was not significantly consumed after protamine administration (sample time 8) or on the first postoperative day (sample time 9). The four patients with high $\mathrm{C} 3 \mathrm{~d} / \mathrm{C} 3$ ratios before the operation had significantly lower preoperative values of $\mathrm{C} 4(10.2 \pm 2.6 \mathrm{mg} / \mathrm{dl})$ than did the nine patients with normal preoperative $\mathrm{C} 3 \mathrm{~d} / \mathrm{C} 3$ ratios $(17.0 \pm 4.6 \mathrm{mg} / \mathrm{dl})$ $(p<0.001)$. This difference persisted during CPB. After protamine administration, $\mathrm{C} 4$ levels were significantly lower in patients with high preoperative $\mathrm{C} 3 \mathrm{~d} / \mathrm{C} 3$ levels $(\mathrm{C} 4=7.5 \pm 3.1 \mathrm{mg} / \mathrm{dl})$ than in patients with normal preoperative $\quad \mathrm{C} 3 \mathrm{~d} / \mathrm{C} 3 \quad(\mathrm{C} 4=11.6 \pm 2.9 \quad \mathrm{mg} / \mathrm{dl})$ $(p<0.05)$. Fig. 4 shows the course of $\mathrm{C} 4$ in the neonates with normal and abnormally elevated preoperative $\mathrm{C} 3 \mathrm{~d}$ / $\mathrm{C} 3$ values.

C4 levels measured after protamine administration and during the first 3 postoperative days did not correlate with catecholamine requirement after the operation or with outcome.

C5a. C5a levels were abnormally elevated at the end of 


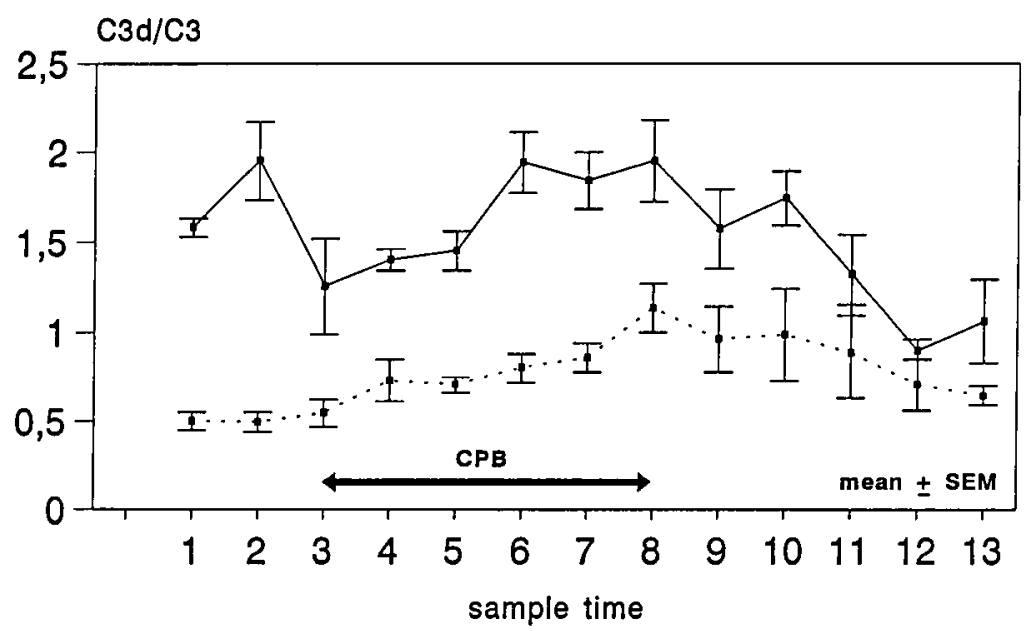

Fig. 3. Course of $\mathrm{C} 3 \mathrm{~d} / \mathrm{C} 3$ before, during, and after $\mathrm{CPB}$ in neonates with normal preoperative $\mathrm{C} 3 \mathrm{~d} / \mathrm{C} 3$ (dotted line, $n=9$ ) and abnormally elevated preoperative C3d/C3 (solid line, $n=4$ ) (from sample time 10 on, $n=7$ for neonates with normal preoperative $\mathrm{C} 3 \mathrm{~d} / \mathrm{C} 3$ levels).

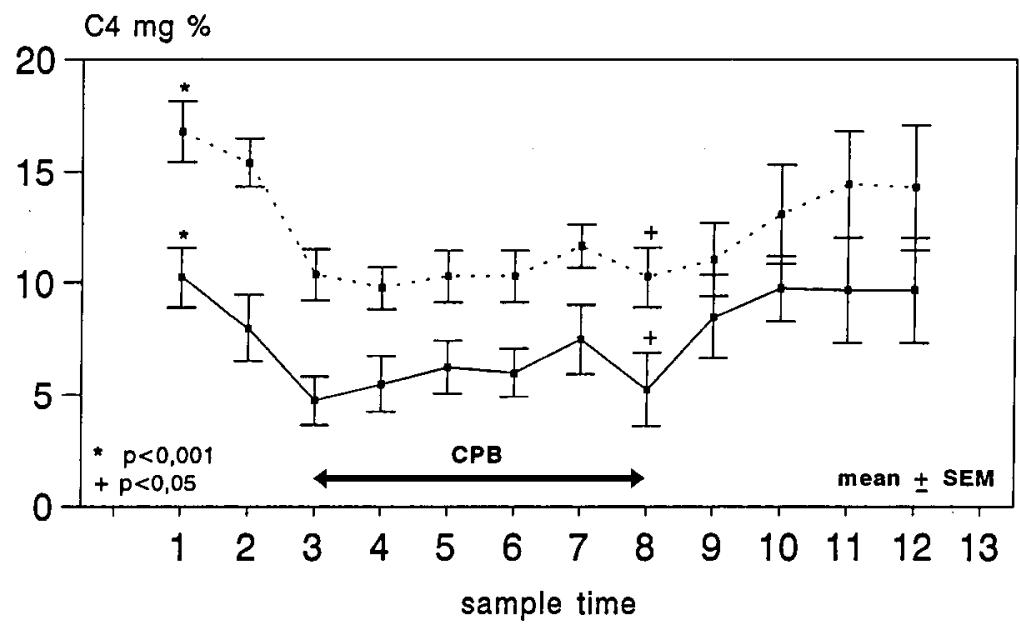

Fig. 4. Course of $\mathrm{C} 4$ before, during, and after $\mathrm{CPB}$ in neonates with normal preoperative $\mathrm{C} 3 \mathrm{~d} / \mathrm{C} 3$ (dotted line, $n=9$ ) and abnormally elevated preoperative C3d/C3 (solid line, $n=4$ ) (from sample time 10 on, $n=7$ for neonates with normal preoperative $\mathrm{C} 3 \mathrm{~d} / \mathrm{C} 3$ levels). $m g \%$, Milligrams per deciliter.

$\mathrm{CPB}$ in the 13 neonates $(\mathrm{C} 5 \mathrm{a}=18.6 \pm 7.3 \mu \mathrm{g} / \mathrm{L})$ (mean $\pm \mathrm{SD}$ ). C5a measured at the end of CPB did not correlate with the duration of CPB. No difference in C5a was observed between patients with normal or elevated preoperative $\mathrm{C} 3 \mathrm{~d} / \mathrm{C} 3$. C5a did not correlate with catecholamine requirement immediately after the operation or with outcome. Values of C3d/C3, C4, and C5a before, during, and after CPB are summarized in Table III.

Leukocytes and neutrophils. In the 10 neonates studied in this respect, leukocyte levels fell from a preoperative value of $10.06 \pm 3.15 \times 10^{9} / \mathrm{L}$ (mean $\pm \mathrm{SD}$ ) to $3.21 \pm 0.64 \times 10^{9} / \mathrm{L} 10$ minutes, after institution of CPB (sample time 3$)(p<0.0001)$. In addition, leukocyte levels fell significantly immediately after extracorporeal circulation was restored after cardiocirculatory arrest (sample time 4) (leukocytes $=2.47 \pm 0.46 \times 10^{9} / \mathrm{L}$ ) $(p<0.0001)$ and again 10 minutes after recirculation (sample time 5) (leukocytes $=2.23 \pm 0.45 \times 10^{9} / \mathrm{L}$ ) $(p<0.05)$. Leukocyte levels remained stable during the rewarming period. Between the end of the rewarming period (sample time 7) and a few minutes after protamine administration (sample time 8), leukocyte levels rose significantly from a value of $2.33 \pm 0.67 \times 10^{9} / \mathrm{L}$ to a value of $7.19 \pm 1.84 \times 10^{9} / \mathrm{L}(p<0.0001)$. Leukocyte levels rose further to a value of $13.19 \pm 3.53 \times 10^{9} / \mathrm{L} 4$ hours after the operation and reached a value of $17.63 \pm 5.81 \times 10^{9} / \mathrm{L}$ on the first postoperative day.

The course of neutrophils was parallel to that of leuko- 
Table III. Measured values of C3d/C3, C4, C5a, leukocytes, neutrophils, and leukocyte elastase before, during, and after $C P B$.

\begin{tabular}{|c|c|c|c|c|c|c|c|}
\hline & \multicolumn{7}{|c|}{ Sample time } \\
\hline & $I$ & 3 & 4 & 5 & 6 & 7 & 8 \\
\hline $\mathrm{C} 3 \mathrm{~d} / \mathrm{C} 3$ & $0.78 \pm 0.48$ & $0.86 \pm 0.55$ & $0.96 \pm 0.41$ & $1.01 \pm 0.41$ & $1.19 \pm 0.62$ & $1.19 \pm 0.54$ & $1.40 \pm 0.56$ \\
\hline $\begin{array}{l}\mathrm{C} 4 \\
(\mathrm{mg} / \mathrm{dl})\end{array}$ & $14.6 \pm 4.7$ & $8.5 \pm 4.0$ & & $8.30 \pm 3.3$ & $8.95 \pm 3.5$ & $8.9 \pm 3.5$ & $10.4 \pm 3.5$ \\
\hline $\begin{array}{l}\mathrm{C} 5 \mathrm{a} \\
(\mu \mathrm{g} / \mathrm{L})\end{array}$ & & & & & & & $18.6 \pm 7.3$ \\
\hline $\begin{array}{l}\text { Leukocytes } \\
\qquad\left(\times 10^{9} / \mathrm{L}\right)\end{array}$ & $10.06 \pm 3.15$ & $3.21 \pm 0.64$ & $2.47 \pm 0.46$ & $2.23 \pm 0.45$ & $2.38 \pm 0.82$ & $2.33 \pm 0.67$ & $7.19 \pm 1.84$ \\
\hline $\begin{array}{l}\text { Neutrophils } \\
\left(\times 10^{9} / \mathrm{L}\right)\end{array}$ & $5.14 \pm 1.18$ & $1.46 \pm 0.35$ & $1.15 \pm 0.27$ & $0.95 \pm 0.31$ & $0.99 \pm 0.44$ & $1.00 \pm 0.31$ & $4.10 \pm 1.18$ \\
\hline $\begin{array}{l}\text { Elastase } \\
\qquad(\mu \mathrm{g} / \mathrm{L})\end{array}$ & & $107 \pm 39$ & & & & & $438 \pm 198$ \\
\hline
\end{tabular}

Sample times are listed in Table II. Vaiues are given as mean \pm SD.

cytes. Neutrophil levels fell significantly from a preoperative value of $5.14 \pm 1.18 \times 10^{9} / \mathrm{L}$ to $1.46 \pm 0.35$ $\times 10^{9} / \mathrm{L} 10$ minutes after beginning of extracorporeal circulation $(p<0.005)$. Neutrophils were at a minimal level after extracorporeal circulation was restored immediately after cardiocirculatory arrest (sample time 5) (neutrophils $=0.95 \pm 0.31 \times 10^{9} / \mathrm{L}$ ) and remained stable until termination of bypass, before protamine administration. Neutrophil levels rose from a value of $1.00 \pm 0.31 \times 10^{9} / \mathrm{L}$ at the end of the rewarming period (sample time 7) to a value of $4.10 \pm 1.18 \times 10^{9} / \mathrm{L}$ immediately after protamine administration (sample time 8) $(p<0.005)$.

No difference in leukocyte and neutrophil count was found before, during, or immediately after $\mathrm{CPB}$ between patients with normal or elevated preoperative $\mathrm{C} 3 \mathrm{~d} / \mathrm{C} 3$ levels. Fig. 5 shows the course of leukocytes and neutrophils during and after $\mathrm{CPB}$ in 10 neonates. Values of leukocytes and neutrophils before, during, and after CPB are summarized in Table III.

Elastase. In the 13 neonates, elastase averaged $106.6 \pm 39.3 \mu \mathrm{g} / \mathrm{L}$ (mean $\pm \mathrm{SD}$ ) after institution of $\mathrm{CPB}$ (sample time 3 ) and rose to a value of $438.0 \pm 198.0$ $\mu \mathrm{g} / \mathrm{L}$ at the end of CPB (sample time 8) (Table III). Elastase release during CPB (elastase at sample time 8 - elastase at sample time 3 ) averaged $331.5 \pm 175.7$ $\mu \mathrm{g} / \mathrm{L}$. Elastase release and elastase level at sample time did not correlate with leukocyte or neutrophil count after protamine administration. Elastase release did not correlate with duration of $\mathrm{CPB}$, with catecholamine requirement immediately after $\mathrm{CPB}$, or with outcome.

\section{Discussion}

The inflammatory response during cardiac operations has not yet been studied in neonates. We report here that full-term neonates show significant complement activation and leukocyte stimulation when undergoing CPB. C3 conversion in this age group is mainly due to the activation of the alternative pathway that occurs primarily in the rewarming period and shows its peak after protamine administration, which is similar to the process in infants and children. ${ }^{7}$ Late phase of complement activation is also involved as shown by the elevated $\mathrm{C} 5 \mathrm{a}$ values measured in all patients at the end of extracorporeal circulation, with consecutive leukocyte elastase release caused by leukocyte stimulation. The course of leukocytes and neutrophils differs in part from that previously described in older children. ${ }^{7}$ After institution of extracorporeal circulation, an initial marked leukopenia and neutropenia occurs, as classically described ${ }^{7-9}$ Using C3d/C3 determination, we could not detect complement activation at this time. Hence, we suggest that early leukopenia may be independent of complement activation and due to physical factors such as hypothermia, increasing leukocyte membrane rigidity, and favoring leukocyte trapping in the lungs and in the extracorporeal circuit. Circulating leukocyte and neutrophil levels decrease further during low-flow CPB most probably in response to activated complement. ${ }^{8}$ In contrast to what is observed in children, leukocyte and neutrophil counts of neonates remain low during the whole rewarming period; also, the peak value of leukocytes and neutrophils after protamine administration is significantly lower in this age group, not reaching preoperative values. This observation might be explained by a limited mobilization of leukocytes from the lungs, bone marrow, and perhaps other hematopoietic organs such as the liver and spleen, probably as a result of an impaired motility of neonatal leukocytes and neutrophils. ${ }^{11}$

Elastase release during $\mathrm{CPB}$ is not different from that 


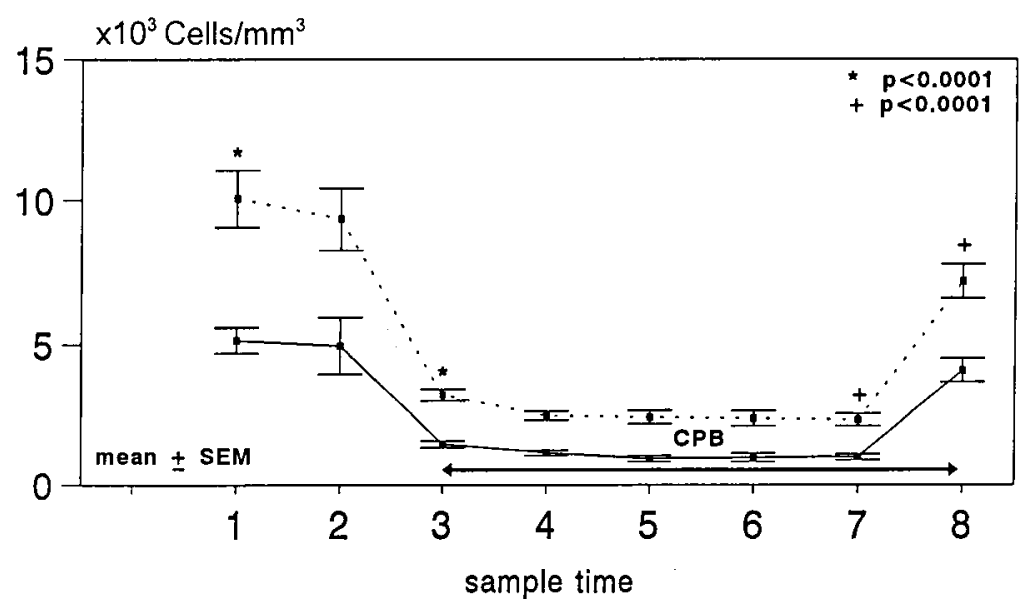

Fig. 5. Leukocyte (dotted line) and neutrophil count (solid line) before, during, and after CPB in 10 neonates.

observed in. children, ${ }^{7}$ indicating that leukocytes of neonates can be stimulated in this regard to the same extent as those of children. The lack of correlation between elastase release and the number of concomitant circulating neutrophils could be due to a nonparallel relation between the effect of CPB on neutrophil stimulation with regard to mobilization or aggregation and degranulation.

Considering complement activation and leukocyte stimulation, neonates, when subjected to the stress of cardiac operation, show a similar inflammatory response to those of older children and adults. Although, in infants and children enrolled in a similar study over the same time period, CPB-related complications have been frequent and a relationship could be shown between postoperative complications and complement activation, ${ }^{7}$ neonates studied in this series had no or only mild CPB-related complications. The complicated postoperative course of patient 13 was due to myocardial ischemia, and the two neonates who died had inadequate cardiac correction and digoxine overdose. Four of the surviving neonates had important capillary leak syndrome that was considered to be CPB-related. ${ }^{12}$ Actually, in our series, no correlation could be found between this complication and the inflammatory reaction during $\mathrm{CPB}$, with regard to complement activation and leukocyte stimulation. The reasons why CPB-related complications appear to be milder in neonates compared with those of older infants and children, in spite of a similar inflammatory response during $\mathrm{CPB}$, are unclear neonates have immature complement receptors on neutrophils ${ }^{5}$ and decreased complement-mediated opsonization ${ }^{10}$ impairing neutrophil migration and phagocytosis, ${ }^{11}$ both possibly limiting the tissue destruction by various inflammatory stimuli occurring during cardiac operation. Nevertheless, in our series of neonates, neutrophils were stimulated during $\mathrm{CPB}$ and liberated proteolytic enzymes as shown by leukocyte elastase release, suggesting complement-induced leukocyte activation. It is noteworthy that all but two patients were treated with $\mathrm{PGE}_{1}$ before the operation for at least 24 hours. Because $\mathrm{PGE}_{1}$ is known to have cytoprotective effects and inhibit leukocyte adherence, ${ }^{13,14}$ pretreatment with $P G E_{1}$ together with naturally impaired neutrophil migration could have been of benefit in the particular situation of neonates undergoing cardiac operation.

Four patients had abnormally elevated preoperative values of $\mathrm{C} 3 \mathrm{~d} / \mathrm{C} 3$ and lower preoperative values of $\mathrm{C} 4$ compared with those of the nine other patients, in the absence of other signs of inflammation or infection. A rational explanation for this observation is actually lacking. Bacterial feto-maternal infection was excluded in all cases. Because our patients were subjected to several manipulations that were able to induce complement activation (delivery, cardiac catheterization with angiography, etc. $)^{15,16}$, the high levels of $\mathrm{C} 3 \mathrm{~d} / \mathrm{C} 3$ and low values of $\mathrm{C} 4$ observed in the four neonates might be discussed with regard to interindividual variations of postnatal complement activation and intrahepatic clearance of $\mathrm{C} 3 \mathrm{~d}$ and synthesis of C4. In spite of the lack of clinical and biologic evidence of impaired liver function in the four neonates with high preoperative $\mathrm{C} 3 \mathrm{~d} / \mathrm{C} 3$ levels, the rapid normalization of $\mathrm{C} 3 \mathrm{~d} / \mathrm{C} 3$ after the operation seems to support the hypothesis of impaired C3d hepatic clearance in the preoperative period.

In conclusion, neonates show important inflammatory response when undergoing $\mathrm{CPB}$ with complement activation and leukocyte stimulation. In our series, CPB-related complications were not dramatic; the physiologic immaturity of complement receptors on the neutrophils of the neonates, maturational defects in phagocytic cells, 
and pretreatment with $\mathrm{PGE}_{1}$ possibly exert a beneficial cytoprotective effect that must be investigated further.

We thank K. Buro-Rathsmann (Dipl.Math.) for assistance in statistical analysis and G. Endres-Winter for the preparation of the manuscript.

\section{REFERENCES}

1. Chenoweth DE, Cooper SW, Hugli TE, et al. Complement activation during cardiopulmonary bypass: evidence for generation of $\mathrm{C} 3 \mathrm{a}$ and $\mathrm{C} 5 \mathrm{a}$ anaphylatoxins. $\mathrm{N}$ Engl $\mathrm{J}$ Med 1981;304:497-503.

2. Kirklin JK, Westaby S, Blackstone EH, et al. Complement and the damaging effects of cardiopulmonary bypass. $\mathbf{J}$ THORAC CARDIOVASC SURG 1983;86:845-57.

3. Strunk RC, Fenton LJ, Gaines JA. Alternative pathway of complement activation in full-term and premature infants. Pediatr Res 1979;13:641-3.

4. Berger M. Complement deficiency and neutrophil dysfunction as risk factors for bacterial infection in newborns and the role of granulocyte transfusion in therapy. Rev Infect Dis 1990;12(Suppl 4):401-9.

5. Bruce MC, Baley JE, Medvik KA, et al. Impaired surface membrane expression of $\mathrm{C} 3 \mathrm{bi}$ but not $\mathrm{C} 3 \mathrm{~b}$ receptors on neonatal neutrophils. Pediatr Res 1987;21:306-11.

6. Johnston RB, Altenburger KM, Atkinson AW, et al. Complement in the newborn infant. Pediatrics 1979;65 (Suppl 5):781-6.

7. Seghaye MC, Duchateau J, Grabitz RG, et al. Complement activation during cardiopulmonary bypass in infants and children: relation to the postoperative multiple system organ failure. J ThORAC CARdiovasc Surg 1993;106: 978-87.

8. Hammerschmidt DE, Stroncek DF, Bowers TK, et al. Complement activation and neutropenia occurring during cardiopulmonary bypass. J THORAC CARdiovasC SURG 1981;81:370-7.

9. Quiroga MM, Miyagishima R, Haendschen LC, et al. The effect of body temperature on leukocyte kinetics during cardiopulmonary bypass. J THORAC CARDIOVASC SURG 1985;90:91-6.

10. Zach TL, Hostetter MK. Biochemical abnormalities of the third component of complement in neonates. Pediatr Res 1989;26:116-20.

11. Klein RB, Fischer TJ, Gard SE, et al. Decreased mononuclear and polymorphonuclear chemotaxis in human newborns, infants and young children. Pediatrics 1977;60:46772.

12. Marath A, Man W, Taylor KM. Histamine release in pediatric cardiopulmonary bypass: a possible role in the capillary leak syndrome. Agents Actions 1987;20:299-302.

13. Bihari DJ, Tinker J. The therapeutic value of vasodilator prostaglandins in multiple organ failure associated with sepsis. Intensive Care Med 1988;15:2-7.

14. Chopra J, Webster RO. PGE $\mathrm{P}_{1}$ inhibits neutrophil adherence and neutrophil-mediated injury to cultured endothelial cells. Am Rev Respir Dis 1988;138:915-20.

15. Herson VC, Block C, Eisenfeld LI, et al. Effect of labor and delivery on neonatal polymorphonuclear leukocyte number and function. Am J Perinatol 1992;9:285-8.

16. Eaton S, Tsay HM, Yost F, et al. Assays for plasma complement activation by $\mathrm{x}$-ray contrast media. Invest Radiol 1990;25:789-92. 